\title{
Regional Integration and Productivity Growth: The Case of EU
}

\author{
Helena Johansson* \\ Lund University
}

\begin{abstract}
Recent research has emphasised the role of trade in productivity growth. The purpose of the present paper is to investigate how regional integration, and the different treatment of member and non-member imports, affects the relation between imports and productivity growth. We focus on the European Union and find intra-union imports to have more of an effect on total factor productivity growth than imports from the outside of the EU, even if only developed nonmember countries are considered.
\end{abstract}

- JEL Classifications: F15, F43, O47, O52

- Key Words: Regional Integration, Inport Competition, Productivity

\section{Introduction}

Although most early empirical studies on the relationship between international trade and (productivity) growth found a positive relationship, recent studies are much more ambiguous. ${ }^{1}$ Since many persuasive arguments point at potential benefits from engaging in international trade this lack of consistency indicates that there still are some dimensions in the relationship which need to be further investigated. One such aspect is the choice of trade partners. This is particularly the case for regional integration arrangements, in which member and non-member imports can be expected to affect productivity growth in the importing member country unevenly. Not only are imports from members and non-members

\footnotetext{
*Corresponding Address: Helena Johansson, Department of Economics Lund University Box 7082, S22007 Lund, Sweden Tel: +46-46-222-8684, Fax: +46-46-222-4613, E-mail: Helena.Johansson@ nek.lu.se ( $2000-$ Center for International Economics, Sejong Institution, all Rights Reserved.
} 
explicitly treated differently in terms of trade barriers, but the integration process per se could also cause intra- and extra-union imports to differ in their impact. Thus, in presence of regional integration, the relationship between imports and productivity growth becomes more complex and an aggregate analysis of the role of import flows, irrespective of origin, is not sufficient to capture the underlying relation. This study focus on the European Union (EU) and investigates empirically the relative productivity effect of intra- and extra-EU imports on productivity growth.

\section{Imports, Productivity Growth and Regional Integration}

Recent research supports the view that trade not only has a once-for-all effect upon the level of productivity, as suggested by traditional trade models, but also affects the rate by which productivity grows. Research on the mechanisms behind endogenous growth indicates that participation in international trade can permanently increase the rate of growth because of, among others, market enlargement. When the market size expands, the knowledge stock upon which further innovation draws increases. ${ }^{2}$ Even if ideas were permitted to flow freely before a deepening of integration, a reduction of trade barriers will still lead to a permanent growth effect since (i) the possibility to use ideas in an extended market increases the return to investment and hence the incentive to innovate, and since (ii) duplicative research is mitigated. ${ }^{3,4}$

By stimulating competition and technical spillovers, it has further been proposed that trade in general and imports in particular could contribute to decreased X-inefficiency, enhance domestic R\&D efforts and lead to a faster diffusion of innovations between countries, all of which leads to a higher rate of productivity growth. ${ }^{5}$ Below, we describe the technical spillover effect and the competition effect and discuss why they are likely to differ between intra- and extra-union imports in regional integration arrangements.

\footnotetext{
${ }^{1}$ Levine and Renelt (1992), Tybout (1992), Englander and Gurney (1994) and Helleiner (1995) are examples of studies in which no robust relationship between trade and growth is encountered while for instance Edwards (1998) finds productivity growth to be positively associated with openness.

${ }^{2}$ Grossman and Helpman (1991a).

${ }^{3}$ Rivera-Batiz and Romer (1991).

${ }^{4}$ As noted by Grossman and Helpman (1991b, Ch. 9) and Feenstra (1996), however, the return to innovation may not increase in a specific country if the potential domestic innovators are not competitive or if human capital is scarce.
} 


\section{A. The Technical Spillover Effect}

Technical progress is considered to be one of the major determinants of productivity growth. ${ }^{6}$ In a given industry technical progress is not only the result of domestic innovation in the industry in question, it is also fuelled by R\&D contributions in other industries as well as in other countries. Imitation and learning can take place when innovations and new technologies disseminate between countries and one channel through which new knowledge spreads is trade contacts. Also, since the greater part of manufactured trade takes place in producer goods, a particular consequence of imports is that the number of varieties of intermediate goods and machinery available in each country increases. This in turn will affect productivity since a better-suited variety could be used in production.

Several studies have tried to capture technical spillovers, for instance Helliwell (1992), who shows that a significant convergence in technical progress has taken place over the past years in the OECD countries. In Park (1995), a panel data set of OECD countries is used and domestic private research is found to have a direct positive impact on both domestic and foreign productivity growth. It is however, difficult to empirically capture trade-related technical spillovers, as Keller (1997a) demonstrates, since international trade is but one of several possible channels, and since these channels often exist simultaneously it is difficult to disentangle them. For example, Keller (1997b) finds international trade to account only for approximately 20 percent of the total domestic productivity effect from foreign $R \& D$.

\section{B. The Competition Effect}

Import competition can influence the rate of productivity growth by reducing prevailing X-inefficiency and by affecting domestic R\&D efforts. ${ }^{7}$ At the firm level, import competition can lessen existing $\mathrm{X}$-inefficiency by reducing internal slack. ${ }^{8}$ In differentiated and imperfectly competitive industries intensified

\footnotetext{
${ }^{5}$ See among others Romer (1992).

${ }^{6}$ In the endogenous growth literature commercially driven innovations in addition to human capital accumulation have been put forward as major engines of growth, see Romer (1986a) and Grossman and Helpman (1991b). See also Grossman and Helpman (1994) for an overview of the role of innovation in the theory of growth.

${ }^{7}$ A main idea behind the suggestion that $\mathrm{X}$-inefficiency affects productivity growth is that static efficiency promotes dynamic efficiency. That is, a firm or an industry which is technically efficient, is more capable of appropriating and developing new technology than an equivalent but less efficient firm since the latter is already unable to master existing knowledge in an optimal way. For a discussion, see e.g. Caves and Barton (1990).

${ }^{8}$ See for instance Horn et al. (1994, 1995).
} 
competition from international trade enforces industrial reorganisation towards a larger scale of production for a fewer number of product varieties. ${ }^{9}$ Import competition can also force $\mathrm{X}$-inefficient firms to exit, so that the average productivity of the industry increases. The empirical evidence is generally supportive. For example, Caves and Barton (1990) find a favourable effect of technical efficiency on productivity growth at the industry level in the US, and Caves and Barton (1990) along with Mayes et al. (1994) find that increased import competition reduces $\mathrm{X}$-inefficiency.

An additional link between import competition and productivity growth is the formers impact on domestic R\&D. It is, however, not evident in which direction this channel works. The presence of competitors with an ability to imitate new innovations reduces the return on $R \& D$ investment and subsequently the incentives to innovate. ${ }^{10}$ In contrast, competition forces firms to upgrade their production structure to remain competitive, thus stimulating $R \& D .{ }^{11}$ The empirical results are mixed. For instance, Bertschek (1995) analyses a panel of West German firms and finds imports to have a positive effect on innovation and Geroski (1988) finds that the direct effect of competition in EU on innovation is positive, while Scherer and Huh (1992) find R\&D/ sales ratios in the US to fall, especially in the short run, when challenged by high-technology import competition.

\section{The Regional Dimension}

The impact on the importing countries' productivity growth may not be the same irrespective of exporting country. ${ }^{12}$ For instance, it may be easier to gain technical spillovers from neighbouring countries than from more distant ones because of cultural ties, language similarities since informal contacts are limited by distance. Empirical evidence is so far scarce but Sjöholm (1996), for example, finds that international trade, but not the geographical distance to trade partners, facilitates the inflow of knowledge to Sweden. The size of the exporting countries' R\&D stock may also matter for the potential to gain technical spillovers. Coe and Helpman (1995) investigate import-related technical spillovers among the OECD countries and find the largest R\&D spillover elasticities from the United States and

\footnotetext{
${ }^{9}$ Helpman (1981) and Krugman (1981).

${ }^{10}$ See for example Romer (1986b).

${ }^{11}$ See for example Porter (1990).

${ }^{12}$ See for example Padoan (1997).
} 
Japan. ${ }^{13}$ Keller (1997b) studies imports of intermediate goods, and finds that the productivity effect on the importing country varies considerably by country of origin, suggesting that the quality of the intermediate good and hence the R\&D underlying it varies, depending upon which country conducted the research.

It is further possible that regional integration affects both the competitive climate as well as the potential for technical spillovers not only among the integrating countries themselves but also between members of the union and third countries, being reflected in disparate impacts on productivity growth from member and non-member imports. Below, we focus on the EU, and discuss why this may be the case.

An important motive behind the removal of intra-EU trade barriers has been to promote competition and the reduction of internal trade barriers is expected to strengthen the intensity of intra-union competition. In contrast, extra-union imports are rendered relatively less competitive due to the different trade barriers which apply depending on whether import comes from intra- or extra-union countries. For example, anti-dumping measures can be used against non-members only. As the actions taken are often quite severe the deterrent effect on competition from the threat of imposing anti-dumping measures or other non-tariff barriers can be rather substantial. ${ }^{14}$

Also the potential for receiving technical spillovers can be positively affected by regional integration. As mentioned above, an effect of regional integration can be to increase the R\&D capital stocks of the individual member countries and thereby the potential for receiving technical spillovers when trading with the other members. So far, we could thus expect intra-union imports to be more beneficial in terms of induced productivity growth than extra-union imports.

However, there is a force working in the opposite direction, since the integration process itself facilitates the development of intra-union activities that undermine competition. ${ }^{15}$ In contrast to what was initially expected, the EU has not lead to an inter-industry specialisation among the members but has instead resulted in a converging pattern of intra-industry trade and an increasing similarity in industry structure. ${ }^{16}$ As the prevalence of monopolistic competition and differentiated products tends to reduce the disciplinary effect of imports and instead leads to

\footnotetext{
${ }^{13}$ See Keller (1997a) and Coe and Hoffmaister (1999) for a discussion on the construction of trade weights intended to capture international R\&D spillovers.

${ }^{14}$ See Messerlin (1989) for a discussion of the anti-competitive effects of EU anti-dumping measures on extra-EU imports.

${ }^{15}$ See Jacquemin and Sapir (1991).
} 
complementarity, this development tends to decrease the relative strength of intraunion competition. For instance, in these types of industries, tacit price leadership is common. Instead of determining prices competitively in accordance with costs, prices are adjusted according to the domestic price leader, permitting less competitive firms to survive. ${ }^{17}$ Further, various anti-competitive forces, like horizontal and vertical agreements as well as intra-firm trade, have been argued to be more prevalent within the EU. If this is the case, a relatively lower impact from intra-union imports on TFP growth could be expected.

\section{The Time Dimension}

Since several counteracting forces could be in play, it can not be predicted $a$ priori whether intra- or extra-union imports have the strongest impact on productivity growth in the EU-member countries. Nor can it be certain that the relative effect is constant over time. For instance, an interaction between an initially strong but diminishing intra-EU competitive effect and an increasing intra-EU spillover process could be present, since the competitive effect and the technical spillovers of intra-union imports are not necessarily constant over time. It could be argued, for example, that the competitive effect of intra-union imports is stronger in the initial years of integration or when a new member is integrated. Within EU, the internal tariff barriers were largely dismantled already in the 1960s and the resulting trade creation should have increased the intra-union competitive pressure. Also the subsequent inclusion of the United Kingdom, Ireland and Denmark in the mid-1970s and the recent southern and northern expansion could have stimulated competition. With the passage of time, the competitive pressure of intra-union imports declines, especially if the industry structure becomes more similar, since the anti-competitive biases discussed above can develop. In contrast, intra-union technical spillovers could increase over time, in particular if the enlarged market size stimulates intra-union $R \& D$ activities. Consequently, it would be of interest not only to investigate the relative impact of intra- and extraunion imports on productivity growth, but also to try to disentangle the competitive effect and the spillover effect from each other and investigate if they vary with origin and over time.

\footnotetext{
${ }^{16}$ Economic geography models à la Krugman (1991) suggest, however, that a further deepening of integration may lead to industry agglomeration, an increase of inter-industry trade and diverging industry structure.

${ }^{17}$ The most illustrative example is the car industry, see e.g. Kirman and Schueller (1990).
} 
The discussion above strongly suggests that the kind of integration matters, in the sense of with whom to integrate. If increased technology spillovers is a main advantage of regional integration, developed countries should preferably choose North-North integration. If, on the other hand, increased competition is a primary gain it could be beneficial for developed countries to integrate with less-developed ones. Less developed countries should try to integrate with developed countries in order to take advantage of both the competition and the spillover effect.

\section{E. Previous Studies and Econometric Concerns}

So far, no attempt to quantify the impact of imports from EU-members contra non-EU members on intra-union productivity growth has been made, but in a seminal study Jacquemin and Sapir (1991) find that intra- and extra-EU imports do not exert the same disciplinary impact on the price-cost margins of domestic industries within the EU, suggesting that the origin of imports matters for the competition effect. ${ }^{18}$ Extra-EU imports, especially from the newly industrialising countries and Japan, are shown to have a substantial disciplinary effect on the price-cost margins, that is a competitive effect, while intra-EU trade has no significant effect at all. Hansson (1992) focuses upon Sweden and analyses how imports from the EU and EFTA (EES) versus non-EES countries, on the one hand, and developed versus developing countries, on the other, have affected Swedish cost-price margins. In agreement with Jacquemin and Sapir (1991), he finds developing countries to have a particular strong impact on cost-price margins. No significant difference between EES and non-EES imports is encountered, however. When investigating whether the tariff reductions between EU and EFTA during the 1970s and 80s led to an intensified import competition in Sweden and Norway, Hansson (1993) finds that although import ratios increased the disciplinary effect, domestic price-cost margins remained unchanged.

In the above-cited studies, the focal point has throughout been on market power and domestic cost-price margins. One weakness of the cost-margin approach is that we do not only have a downward pressure from imports on prices but also on costs, and further, those high prices may allow for high costs rather than high costprice margins. A complementary way of addressing the problem is therefore to use a more direct performance measurement, i.e. TFP growth. An additional reason for addressing TFP growth is that the welfare gains of enhanced TFP growth,

\footnotetext{
${ }^{18}$ High cost-price margins indicate domestic market power and low levels of competition.
} 
which is a dynamic gain from trade, are likely to be larger than the gains from the price effect. $^{19}$

\section{The Model}

In this section, we specify a conventional production function, which is used to capture the effects of imports and technology spillovers on TFP growth. In each country, sectoral output at time $t, Y(t)$, is a function of the level of labour and capital inputs, $L(t)$ and $K(t)$

$$
Y(t)_{i c}=A_{i c}(t) f\left(K(t)_{i c}, L(t)_{i c}\right)
$$

where $i=1, \ldots, I$ denotes industry and $c=1, \ldots, N$ country. $A$ is the level of TFP at time t. Capital is assumed to be mobile across sectors, so that the marginal productivity of capital and labour respectively is equalised across sectors. Marginal productivity is further assumed to be equal across countries. By differentiating the logarithms of equation (1) with respect to time, an expression for the relative growth rate of the sectoral production is found:

$$
\left[\frac{\dot{Y}}{Y}\right]_{i c}=\left[\frac{\dot{A}}{A}\right]_{i c}+\beta_{1}\left[\frac{\dot{K}}{K} \frac{K}{Y}\right]_{i c}+\beta_{2}\left[\frac{\dot{L}}{L} \frac{L}{Y}\right]_{i c} .
$$

$\beta_{1}$ and $\beta_{2}$ are the marginal physical product of capital and labour, and $\dot{X}$ is the time derivative of $X$. The relative growth rate of TFP, $\dot{A} / A$, is hypothesised to be a function of import competition and technology transfers. Import penetration as measuered by the import share of domestic sales, sectoral value added, sectoral consumption or such like, is commonly used to capture both phenomenon. A more explicit way to model international technology spillovers is to use an import-share weighted sum of trade partner's R\&D, in accordance with Coe and Helpman (1995):

$$
I T S P_{i c}=\sum_{b \neq c} \frac{R D_{i b}}{Y_{i b}} \frac{M_{i b c}}{M_{i c}} \frac{M_{i c}}{C_{i c}},
$$

where $C$ is total consumption, i.e. total production plus imports minus exports. The potential to receive technology transfers depends first on the degree to which trade partners engage in R\&D activities. This is measured as trade partner's share of

\footnotetext{
${ }^{19}$ For instance, studies by Domowitz, Hubbard and Petersen (1986) and De Rosa and Goldstein (1981) find the price reducing effect statistically significant but small.
} 
R\&D expenditures in value added in industry $i$. Second, the composition of trade, i.e. the share of imports in industry $i$ in country $c$ coming from country $b$, matters since trade with R\&D intensive countries are more likely to result in spillovers, $\Sigma\left(M_{i b c} / M_{i c}\right)=1$. Third, comparing two countries with identical trade composition but with differences in openness, the more open country, in terms of fraction of imports in total consumption in industry $i$, is more likely to benefit from technology transfers because of the higher degree of exposure to foreign technology.

It is possible that technology transfers are more prominent in relatively backward industries, i.e. industries at relatively lower TFP levels. ${ }^{20}$ We construct the technology gap, GAP, as the ratio of the TFP level in each industry and in each country to the corresponding TFP level in the country and industry in the world with the highest TFP level:

$$
G A P_{i c}=\frac{Y_{i c} /\left(L_{i c}^{w} * K_{i c}^{(1-w)}\right)}{Y_{j k} /\left(L_{i k}^{w} * K_{j k}^{(1-w)}\right)}
$$

$j$ is the industry in country $k$ with the highest TFP level in 1973. The inputs are weighted by $w$, the labour share in value added, which is estimated as labour compensation divided by value added. By interacting the technology transfer variable and the GAP variable it is possible to investigate whether the importance of technology transfers differ between sectors that are relatively backward and sectors that are close to the technology frontier.

In addition to the variables specified above, $R \& D$ intensity is included among the explanatory variables. We thus have

$$
\begin{aligned}
{\left[\frac{Y}{Y}\right]_{i c}=} & \sum_{i} \beta_{0 i}+\sum_{t} \beta_{0 t}+\sum_{c} \beta_{0 c}+\beta_{1}\left[\frac{K}{K} \frac{K}{Y}\right]_{i c}+\beta_{2}\left[\frac{L}{L} \frac{L}{Y}\right]_{i c}+\beta_{3}\left[\frac{R D}{Y}\right]_{i c}+ \\
& \beta_{4} I T S P_{i c}+\beta_{5} M_{i c}+\beta_{6} G A P_{i c}+\beta_{7} I T S P_{I C} * G A P_{i c}+v_{i c}
\end{aligned}
$$

where $Y$ is value added, $R D$ is $\mathrm{R} \& \mathrm{D}$ expenditures, $M$ is the share of imports in value added which can be divided in $M E U$ and $M N E U$, the share of imports from other EU-members (non-EU-members) in value added. Equivalently, ITSP is the technology transfer variable which can be divided in ITEU (ITNEU), technology transfers from other EU-members versus technology transfers from non-EUmembers. $i, t$ and $c$ are industry, time and country effects respectively, and last, a zero-mean error term, $\mathrm{v}$, is added to the expression.

\footnotetext{
${ }^{20}$ See for example Baumol, Nelson and Wolff (1994) for a discussion of convergence.
} 
If regional integration affects the relative intensity of import competition and the relative potential to benefit from technical spillovers, the impact of intra- and extra-EU imports as well as intra- and extra-EU technology transfers is expected to differ. As discussed above, several scenarios are feasible. One possibility is that technical spillovers are a major link between import intensity and TFP growth. Since the EU has several of the world's most important innovators as members and integration could have stimulated extended intra-EU activities as well as facilitated technical spillovers, we might expect intra-EU imports to exercise a relatively strong impact on TFP growth while extra-EU imports would be less prominent in promoting TFP growth. Another possibility is that the effect detected by Jacquemin and Sapir (1991) could be present also in the case of productivity growth. If imports affect TFP growth mainly through increasing the competitive pressure but extra-EU imports exert a higher competitive pressure than intra-EU imports; we would then expect the coefficient of $M N E U$ to be positive and the coefficient of $M E U$ to be smaller in size or even statistically insignificant. On the other hand, the differentiation of internal and external trade barriers might reduce extra-EU competition causing intra-EU imports to have a relatively higher competitive effect and thus a larger impact on TFP growth.

\section{The Data}

The empirical estimations are carried out on a sample of four EU members: France, Germany, Italy and the United Kingdom and 22 manufacturing industries. ${ }^{21}$ All the countries in the sample are large in an economic sense and have a relatively high import ratio. Relatively aggregated sectoral data are used permitting inter-industry technical spillovers of imported technology within the sectors. ${ }^{22}$ Production is measured by value added and employment is measured by the number of employees plus self-employed, owner proprietors and unpaid family workers. The data on industry import flows by country of origin and destination are available in nominal US\$ which were converted to real national currencies using exchange rates obtained from STAN and price deflators from the World Tables (1995). ${ }^{23}$ R\&D expenditures are available at the same aggregation

\footnotetext{
${ }^{21}$ Classified according to the adjusted ISIC revision 2 classification.

${ }^{22}$ The data is obtained from the OECD Structural Industrial Analysis Database (STAN, 1994) and three STAN compatible databases: the OECD Analytical Business $R \& D$ Database (ANBERD, 1994), the OECD Industrial Sectoral Database (ISDB, 1994) and the OECD Bilateral Trade Database (BTD, 1994).
} 
level as the rest of the data. Data on capital stock and labour compensation are obtained from ISDB. Data on the fixed capital stock is available at the two-digit level, i.e. for nine industries and these estimates are used to proxy the capital variable in sub-industries. ${ }^{24}$

The focus is upon the long run relationship between TFP growth, import penetration and technology transfers, but it may be difficult to discern the expected positive long run association between imports and productivity growth. First, imports are often drawn to low-productivity sectors in which the importing country has a comparative disadvantage. Secondly, productivity growth has been found to be procyclical, that is in when output expands productivity typically grows relatively faster than in times of recession. If an increase in imports results in a contraction of the domestic industry, productivity growth may thus fall. Hence, short run data often exhibit a negative association between trade and productivity. ${ }^{25}$ We therefore calculate average values and the average growth rates over three time periods (1973-79, 1979-85 and 1985-90). ${ }^{26}$ We follow Englander and Gurney (1994) and choose the time periods so that the end points roughly correspond to business cycle peaks within the OECD, in order to level off short run variations in capacity utilisation.

\section{Empirical Estimations}

We first test and find that in each of the three cross-sections, parameters are stable across countries. Next, we are interested in whether coefficients change over time. In order to place restrictions on parameters across time, the dependent variable for the three periods is stacked while the matrices containing the explanatory variables are placed in a diagonal with zeros in all off-diagonal positions. When no restrictions are placed on the system, we are in fact running the three different regressions in one, with separate coefficients for each variable in each time period. Parameter stability over time is then tested for each

\footnotetext{
${ }^{23}$ The OECD has converted the foreign trade data from UN SITC to an ISIC classification in order to match STAN.

${ }^{24}$ Capital growth has also been proxied by investment, i.e. the capital variable in equation (5) was replaced with $\left(I_{i c} / Y_{i c}\right)$. There are several potential problems with this approach, for instance, the rate of growth of capital is overestimated (underestimated) in capital (labour) intensive industries. The proxy did not perform well in the empirical part suggesting that it is a poor measure.

${ }^{25}$ See for example Harrison and Revenga (1995).
${ }^{26}$ The average growth rates have been calculated according to $\left[\frac{\dot{X}}{X}\right]=\frac{1}{T}\left(\ln X^{t}-\ln X^{0}\right)$.
} 
explanatory variable by restricting the triplets of coefficients to being equal across periods. When the null hypothesis can not be rejected, the preferred specification is the restricted regression in which the equality of coefficients over time is imposed. Except for the technology transfer variable, ITSP, all parameters are stable across time. In regressions excluding the ITSP variable it is thus possible to pool the cross-sections.

The ITSP variable is found to be highly correlated with domestic R\&D investments. ${ }^{27}$ This is hardly surprising since industry level data is used. Although countries may specialise and conduct research in different industries, some industries are by their nature more or less $R \& D$ intensive than others and it is possible that the ITSP variable picks up this pattern. Further, the ITSPEU variable, technology transfers from other EU-members and the ITSPNEU variable, technology transfers from non-EU-members are also highly correlated, which precludes us from drawing any inference on their separate effects on TFP growth. ${ }^{28}$ When the share of $\mathrm{R} \& \mathrm{D}$ expenditures is replaced by a dummy variable for $R \& D$ intensive sectors the partial correlation between the $R \& D$ variable and the ITSP variable is reduced albeit still high. Merely looking at the partial correlation among the variables may not give a sufficient picture. In order to check the severity of the multicollinearity problem, we run separate regressions for each time period and compare the overall adjusted $\mathrm{R}^{2}$ 's in the regressions with the adjusted $\mathrm{R}^{2}$,s obtained using the $R D$ dummy variable and the ITSP variable, respectively, as dependent variables. In the second and third time period, the individual adjusted $\mathrm{R}^{2}$ s are indeed higher than the overall adjusted $\mathrm{R}^{2}$ 's suggesting that we should be concerned with the problem. In the following regressions we focus on imports and exclude the ITSP variable for the time being.

The cross-sections are pooled and four sets of regressions are carried out: First, only total imports is included. Second, imports are divided in extra- and intraunion imports. Third, non-OECD countries are removed from the extra-EU import variable, finally total OECD imports is contrasted against imports from non-

\footnotetext{
${ }^{27}$ The partial correlation are $0.87,0.81$ and 0.83 in the three time periods.

${ }^{28}$ In an attempt to solve both problems the ITSP variable was replaced by the ratio of trade partners import weighted $R \& D$ expenditures to total $R \& D$, defined as domestic $R \& D$ expen ditures plus partner countries weighted $R \& D$ expenditures. By interacting with $\left(\mathrm{M}_{\mathrm{ic}} / \mathrm{C}_{\mathrm{ic}}\right)$, the overall import share, openness was taken into account. Even though the multicollinearity problem more or less disappears, this construction is, however, not successful. Indeed, a very low significance level hints at problem with misspecification.
} 
OECD countries. Looking at the first regressions in Table 1 below, we note that the magnitudes of the coefficients capturing the marginal productivity of employment and capital are somewhat high. The means and standard deviations of the respective variables are $0.0066(0.018)$ and $0.025(0.11)$, with standard deviations

Table 1. The impact of imports on TFP growth in a sample of EU countries

\begin{tabular}{|lllllllll|}
\hline Variable & \multicolumn{2}{c}{$\begin{array}{c}\text { (i) } \\
\text { preferred }\end{array}$} & \multicolumn{2}{c}{$\begin{array}{c}\text { (ii) } \\
\text { preferred }\end{array}$} & \multicolumn{2}{c}{$\begin{array}{c}\text { (iii) } \\
\text { preferred }\end{array}$} & (iv) \\
preferred
\end{tabular}

Notes: The dependent variable is growth in value added. Since parameters are stable over time, the three cross-sections are pooled. The parameter estimates of $M E U$ (intra-EU imports) and $M N E U$ (extra-EU imports) are significantly different from each other at the 5\% level (significance level 0.029) in the preferred specification and at the $1 \%$ level (significance level 0.0065) in the specification with an aggregate employment coefficient. The parameter estimates of MEU and MRESTOECD (imports from OECD members that are not members in the EU) are significantly different from each other at the $10 \%$ level (significance level 0.095) in the preferred specification and at the 5\% level (significance level 0.039) in the other specification. MTOECD measures imports from all OECD countries, while MNONOECD is imports from non-OECD countries. In the preferred specification, the 22 industry employment coefficients are not reported. Industry dummies are included in all regression. t-statistics are found in brackets and three, two and one asterisks denote statistical significance levels at the 1\%,5\% and 10\% levels respectively. 
in parentheses, indicating that the assumption of equal marginal productivity of labour and capital across industries may be questioned. In an alternative specification the marginal productivities are assumed to be equal in the same industries across countries and time but different between industries. The marginal productivity of labour but not of capital is found to differ across industries. ${ }^{29} \mathrm{By}$ using the Davidson-McKinnon (1981) J-test the preferred specification turns out to be the one with separate slope coefficients for the employment variable. ${ }^{30}$ The results of the two specifications are in accordance with each other, with the exception of the $M N E U$ coefficient in regression (ii) which is insignificant in the preferred specification but negative and significant in the specification with an aggregated employment variable. Since there are few observations per industry the estimates of the industry specific marginal produc-tivity for employment are shaky with several insignificant coefficients. ${ }^{31}$ In Table 1 , results from both the specification with an aggregated employment variable and with separate industry are presented, except from the last regression. ${ }^{32}$

In regressions (i), where the share of total imports is included, the coefficient of imports fails to be significant in both specification. One feasible explanation for this inability to find a positive correlation could be, as argued above, that the choice of trading partner matters in the sense that import origin plays a role. In regression (ii), the role of regional integration is examined. We divide imports into intra- and extra-union imports in order to investigate whether their influence on TFP growth differs. ${ }^{33}$ In contrast to the preceding result, imports, in terms of intraunion imports, is found to be statistically significant. No positive effect of nonmember imports, $M N E U$, is, however, encountered. Instead, a negative, and in the aggregated specification significant, association is present. ${ }^{34}$ Further, the parameter estimates of $M E U$ and $M N E U$ are significantly different from each other at the 5 percent level. We thus find intra-union imports to positively

$\overline{{ }^{29} \text { The significance levels }}$ are 0.024 and 0.87 for labour and capital respectively.

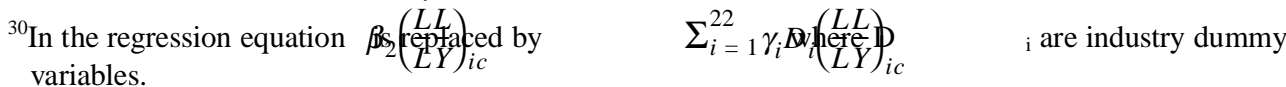

${ }^{31}$ In the tables below, the 22 employment coefficients are not presented.

${ }^{32}$ Heteroskedasticity is tested for, but not found, by regressing the squared residuals on the predicted values.

${ }^{33}$ The partial correlation between $M E U$ and $M N E U$ are found in Table A1 in the appendix.

${ }^{34}$ The significance of the negative $M N E U$ coefficient is also sensitive to other changes in the specification, indicating that the result is not robust.
} 
influence TFP growth while extra-union imports have no such effect, indicating a beneficial effect from European integration on intra-EU TFP growth. Since the coefficient of the $M E U$ variable is stable across time there is no sign of a time effect, i.e. that the influence of intra-union imports changes over time.

However, extra-EU imports are not homogenous, but composed of imports from both industrialised and less developed countries, and it is possible that the detected difference between member and non-member imports stems from the inclusion of non-developed countries in the extra-EU import variable. Instead of reflecting a difference between imports from EU-members and non-members, a North-South dimension could be concealed in the data material. Therefore, the $M N E U$ variable is replaced by MOECD, imports from the rest of the OECD, i.e. OECD countries, which are not members of the EU in order to investigate whether the results

Table 2. The impact of technology transfers and imports on TFP growth in a sample of EU countries

\begin{tabular}{|c|c|c|c|c|c|c|}
\hline Variable & $\begin{array}{c}(\mathrm{v}) \\
1973-79\end{array}$ & $1979-85$ & $1985-90$ & $\begin{array}{c}\text { (vi) } \\
1973-79\end{array}$ & $1979-85$ & $1985-90$ \\
\hline Constant & $\begin{array}{l}0.027 * * \\
(1.96)\end{array}$ & $\begin{array}{l}0.027 * * \\
(1.96)\end{array}$ & $\begin{array}{l}0.027 * * \\
(1.96)\end{array}$ & $\begin{array}{l}0.027 * * \\
(2.08)\end{array}$ & $\begin{array}{l}0.027 * * \\
(2.08)\end{array}$ & $\begin{array}{l}0.027 * * \\
(2.08)\end{array}$ \\
\hline$C A P$ & $\begin{array}{l}0.12 \text { *** } \\
(5.35)\end{array}$ & $\begin{array}{l}0.12 * * * \\
(5.35)\end{array}$ & $\begin{array}{l}0.12 * * * \\
(5.35)\end{array}$ & $\begin{array}{l}0.11^{* * *} \\
(5.45)\end{array}$ & $\begin{array}{l}0.11 \text { *** } \\
(5.45)\end{array}$ & $\begin{array}{l}0.11 * * * \\
(5.45)\end{array}$ \\
\hline$M E U$ & & & & $\begin{array}{l}0.021 * * * \\
(2.85)\end{array}$ & $\begin{array}{l}0.021 * * * \\
(2.85)\end{array}$ & $\begin{array}{l}0.021 \text { *** } \\
(2.85)\end{array}$ \\
\hline$M N E U$ & & & & $\begin{array}{l}-0.011 \\
(-0.917)\end{array}$ & $\begin{array}{l}-0.011 \\
(-0.917)\end{array}$ & $\begin{array}{l}-0.011 \\
(-0.917)\end{array}$ \\
\hline ITSP & $\begin{array}{l}-0.15 \\
(-1.62)\end{array}$ & $\begin{array}{l}0.14 * * \\
(2.41)\end{array}$ & $\begin{array}{l}0.057 \\
(0.891)\end{array}$ & $\begin{array}{l}-0.12 \\
(-1.32)\end{array}$ & $\begin{array}{l}0.12 * * \\
(2.15)\end{array}$ & $\begin{array}{l}0.049 \\
(0.817)\end{array}$ \\
\hline GAP & $\begin{array}{c}-0.030 * * \\
(-2.38)\end{array}$ & $\begin{array}{c}-0.030 * * \\
(-2.38)\end{array}$ & $\begin{array}{c}-0.030 * * \\
(-2.38)\end{array}$ & $\begin{array}{c}-0.032 * * * \\
(-2.68)\end{array}$ & $\begin{array}{c}-0.032 * * * \\
(-2.68)\end{array}$ & $\begin{array}{c}-0.032 * * * \\
(-2.68)\end{array}$ \\
\hline$I T S P^{*} G A P$ & $\begin{array}{l}0.32 * \\
(1.80)\end{array}$ & $\begin{array}{l}-0.12^{*} \\
(-1.91)\end{array}$ & $\begin{array}{l}-0.074 \\
(-0.880)\end{array}$ & $\begin{array}{l}0.25 \\
(1.43)\end{array}$ & $\begin{array}{l}-0.10^{*} \\
(-1.73)\end{array}$ & $\begin{array}{c}-0.0716 \\
(-0.894)\end{array}$ \\
\hline Adj. $R^{2}$ & 0.46 & & & 0.51 & & \\
\hline $\begin{array}{l}\text { Number of } \\
\text { observations }\end{array}$ & 243 & & & 242 & & \\
\hline
\end{tabular}

Note: The dependent variable is growth in value added. In the two regressions, the coefficients that are stable over time are restricted to be equal across the three time periods. Only the preferred specification with separate slope coefficients for the employment variable is presented, the 22 industry employment coefficients are not reported. MEU (MNEU) is imports from EU-members (non-members). ITSP is the import-share-weighted sum of trade partners $\mathrm{R} \& \mathrm{D}$ expenditures, $G A P$ is a catching-up variable and $I T S P^{*} G A P$ is an interaction term. Industry dummies are included in all regression. t-statistics are found in brackets and three, two and one asterisks denote statistical significance levels at the $1 \%, 5 \%$ and $10 \%$ levels respectively. 
depend on the construction of the $M N E U$ variable. As before, the coefficient of $M E U$ is significant in regression (iii) while the coefficient of the $M O E C D$ variable is insignificant, the coefficients still being significantly different from each other. Total import is also divided in imports from OECD countries (MTOECD) contra imports from non-OECD (MNONOECD) countries in regression (iv), but neither coefficients are significant.

Thus, a positive relationship between intra-union imports and intra-union TFP growth is found. This finding supports the view that European integration has been growth enhancing and that integration is beneficial for the members since trade amongst the members affect productivity growth positively while no such effect is found concerning trade outside of the EU. The coefficients are significantly different from each other, so that intra-union imports indeed have a stronger effect on TFP growth than imports from other OECD countries. There is no indication that the encountered relationship is instead explained by trade with developed countries contra less developed countries.

An interesting interpretation of the weak association between imports from other OECD countries and TFP growth is that other channels like foreign direct investments (FDI) could be more important. ${ }^{35}$ Many of the non-EU member OECD countries like for instance the US and Japan, have engaged in substantial FDI in the EU. It is possible that FDI, which often involves the transfer of firmspecific knowledge to subsidiaries, is considered to be a more substantial threat than imports. Also, parts of the intra-EU trade are a result of extra-EU FDI. ${ }^{36}$ In our analysis, this kind of imports is regarded as intra-EU in origin when in fact a non-EU member, is the original source. ${ }^{37}$

Import shares are often used to capture both competition and technology transfer. In an attempt to separate the two effects from each other, a technology transfer variable is used. However, as already noted above there are some problems. First and foremost, due to multicollinearity it is not possible to compare intra-and extra-union technology transfers, as was a main objective. Multicollinearity is further a problem when it comes to domestic R\&D intensity,

\footnotetext{
${ }^{35}$ See for example Blomström and Kokko (1997).

${ }^{36}$ One notable example is the car industry: for example, the Germany based European Ford exports cars to other EU members and in the U.K., Japanese car companies have made substantial FDI.

${ }^{37} \mathrm{~A}$ general problem in this kind of analysis is the increasing amount of intra-firm trade that is included in the reported trade flows but cannot be separated from "traditional" trade flows. Intra-firm trade is not expected to yield any positive effects on TFP growth and if trade between members and non-members incorporate intra-firm trade to a higher extent than member trade we have a further problem when comparing the effects of the two.
} 
if domestic $R \& D$ is excluded from the regressions, it is possible that the intended technology transfer variable only works as a proxy for $R \& D$ intensive industries. Depending on whether trade variables are included or not, the estimates and the significance of the technology transfer coefficients differ, pointing at the difficulty to disentangle the two effects from each other. Finally, the results from the two specifications are not wholly consistent, necessitating further caution regarding the interpretation of the results.

As can be seen in regression (v), when the trade variables are excluded, the interaction term is positive and significant in the first time period, indicating catching-up related technology transfers in the early stages of integration. This effect disappears, however, when $M E U$ and $M N E U$ are added in regression (vi) ${ }^{38}$ In the second time period, 1979-85, the interaction term is negative and significant in both regressions suggesting that technology transfers are more important for industries close to the technology frontier. However, in a specification with an aggregate employment variable (not reported) this coefficient just fails to be significant at the $10 \%$ level, suggesting that the relationship may not be robust. The technology transfer variable itself (ITSP) is significant only in the second time period. Thus, no clear results are obtained when including the technology transfer variable. It should be noted, however, that the $M E U$ variable is still statistically significant when the technology transfer variable is included.

\section{Concluding Remarks}

In conformity with several studies in which trade and growth are found to be uncorrelated, total imports is found to have no impact on TFP growth in the EU in our study. However, when regional integration is taken into account and total imports are divided according to origin in EU-member and non-EU-member imports, imports from other EU-members have a positive impact on TFP growth over the 1973-90 period. This impact is statistically different from the effect of imports from non-EU members as well as from OECD countries that are not members in EU. Thus, trade amongst the EU-members has a stronger effect on productivity growth than trade with non-members, even if the non-members are developed countries. Hence, the anti-competitive bias within the EU detected by Jacquemin and Sapir (1991) is not found to carry over to the case of TFP growth.

\footnotetext{
${ }^{38} G A P$ was also interacted with $I M P, M E U$ and $M E U$ but non of the interaction variables are significant.
} 
Instead, we do find a beneficial effect from integration displayed by a relatively higher impact from intra-union imports on TFP growth, providing a hint that regional integration per se does effect TFP growth. No time effect is found, the magnitude of the intra-union effect is constant over time. An attempt is also made to explicitly take technology transfers into account. It is, however, not possible to distinguish between intra- and extra-union technology transfers.

\section{Acknowledgements}

I am grateful for valuable comments and suggestions from Yves Bourdet, Magnus Blomström, Henrik Braconier, Mick Dunford, Pär Hansson and an anonymous referee. Financial support from the Swedish Council for Research in the Humanities and Social Sciences (HSFR) is gratefully acknowledged. The paper has been presented at the Nordic Workshop in International Economics, Stockholm (1998).

Date accepted: 19 July, 2000

\section{References}

Baumol, W. J., R. R. Nelson and E. N. Wolff (1994), Convergence of Productivity: Crossnational Studies and Historical Evidence, Oxford University Press: Oxford, New York.

Bertschek, I. (1995), "Product and Process Innovation as a Response to Increasing Imports and Foreign Direct Investment", The Journal of Industrial Economics XLIII(4) 341-357.

Blomström, M. and A. Kokko (1997), "Regional Integration and Foreign Direct Investment," The World Bank Policy Research Working Paper 1750.

Caves, R. and D. Barton (1990), Efficiency in US. Manufacturing Industries. The MIT Press: London, England.

Coe, D. T. and E. Helpman (1995), "International R\&D Spillovers, "European Economic Review 39, 859-87.

Coe, D. T. And Hoffmaister (1999), “Are There International R\&D Spillovers Among Randomly Matched Trade Partners? A Response to Keller" IMF Working Paper 99/18. The International Monetary Fund.

Davidson, R. And J. G. McKinnon (1981), "Several Tests for Model Specification in the Presence of Alternative Hypotheses," Econometrica 49, 781-94.

De Rosa, L. A. and M. Goldstein (1981). "Import Discipline in the US Manufacturing Sector" International Monetary Fund Staff Paper, 600-634.

Domowitz, I., G. Hubbard and B. Petersen (1986), "Business Cycles and the Relationship Between Concentration and Cost-Price Margins," The RAND Journal of Economics 17, 1-17. 
Edwards, S. (1998), "Openness, Productivity and Growth: What Do We Really Know?," The Economic Journal 108, 383-98.

Englander, A. S. and A. Gurneuy (1994), "Medium-term Determinants of OECD Productivity," OECD Economic Studies, No. 22.

Feenstra, R. C., (1996), "Trade and Uneven Growth," Journal of Development Economics, 49(1), 229-56.

Geroski P. A., (1988), "Competition and Innovation", in Research on the Cost of NonEurope, Vol. 2, The EU Commission.

Grossman, G. and E. Helpman (1991a), "Trade, Knowledge Spillovers and Growth," European Economic Review 35(3), 1247-80.

Grossman, G. and E. Helpman (1991b), Innovation and Growth in the Global Economy, MIT Press Cambridge, MA.

Grossman, G. and E. Helpman (1994), "Endogenous Innovation and the Theory of Growth," Journal of Economic Perspectives 8(1), 23-44.

Hansson, P. (1992), "The Discipline of Imports: The Case of Sweden," The Scandinavian Journal of Economics 94(4), 589-97

Hansson, P. (1993), 'The Effects of Trade Barriers on Domestic Market Performance:

Evidence from the Swedish and Norwegian Manufacturing Industries," in Fagerberg, J. and L. Lundberg (Eds.) European Economic Integration: A Nordic Perspective, 10728, Aldershot, U.K.; Brookfield, Vt. and Sydney: Ashgate, Avebury.

Harrison, A. E. and A. Revenga (1995), "The Effects of Trade Policy Reform: What Do We Really Know?," NBER Working Paper 5225.

Helleiner, G. K. (1995), 'Trade, Trade Policy and Industrialization Reconsidered," World Development Studies 6. UNU World Institute for Development Economic Research. Helliwell, J. F. (1992), "Trade and Technical Progress," NBER Working Paper 4226.

Helpman, E. (1981), "International Trade in the Presence of Product Differentiation, Economies of Scale and Monopolistic Competition: A Chamberlin-Heckscher-Ohlin Approach," Journal of International Economics 11, 305-40.

Horn, H., H. Lang and S. Lundgren (1995), "Managerial Effort Incentives, X-Inefficiency and International Trade," European Economic Review 39, 117-38.

Jacquemin, A. and A. Sapir (1991), "Competition and Imports in the European Market," in European Integration: Trade and Industry, edited by L. A. Winters and A. Venables. Cambridge University Press.

Keller, W. (1997a), "Are International R\&D Spillovers Trade-Related? Analyzing Spillovers Among Randomly Matched Trade Partners," NBER Working Paper 6065.

Keller, W. (1997b), 'Trade Patterns, Technology Flows, and Productivity Growth", World Bank Working Paper 1831.

Kirman, A. and N. Schueller (1990), "Leadership and Discrimination in European Car Markets," The Journal of Industrial Economics 34(1), 69-91.

Krugman, P. R. (1981), "Intraindustry Specialization and the Gains from Trade," Journal of Political Economy 89, 959-73.

Krugman, P. (1991), Geography and Trade, The MIT Press, Cambridge, Massachusetts, 
London, England.

Levine, R. and D. Renelt (1992), "A Sensitivity Analysis of Cross-Country Growth

Regressions," The American Economic Review 82(4), 942-63.

Mayes, D., C. Harris and M. Lansbury (1994), Inefficiency in Industry, Harvester and

Wheatsheaf: New York, London, Toronto.

Messerlin, P. A. (1989), "The EC Anti-dumping Regulations: A First Economic

Appraisal, 1980-85," Weltwirtschaftliches Archiv 125, 563-87.

Padoan, P. C. (1997), “Technology Accumulation and Diffusion: Is There a Regional

Dimension?" World Bank Policy Research Working Paper 1781.

Park, W. G. (1995), "International R\&D Spillovers and OECD Economic Growth," Economic Inquiry 33, 571-591.

Porter, M. E. (1990), The Competitive Advantage of Nations, Free Press: New York.

Rivera-Batiz, L. A. and P. M. Romer (1991), "Economic Integration and Endogenous

Growth," Quarterly Journal of Economics 106(2), 531-56.

Romer, P. M. (1986a), "Endogenous Technological Change," Journal of Political Economy 98, 71-102.

Romer, Paul M. (1986b), Increasing Returns and Long-run Growth, Journal of Political Economy 94(5), 1002-37.

Romer, P. M. (1992), “Two Strategies for Economic Development: Using Ideas and

Producing Ideas," World Bank Annual Conference on Economic Development,

Washington DC, The World Bank.

Scherer, F. M. and K. Huh (1992), "R\&D Reactions to High-Technology Import

Competition," The Review of Economics and Statistics, 202-12.

Sjöholm, F. (1996), "International Transfer of Knowledge: The Role of International

Trade and Geographic Proximity," Weltwirtschaftliches Archiv 132(1), 97-115.

Tybout, J. R., (1992), "Researching the Trade/Productivity Link: New Directions," The

World Bank Economic Review 6(2).

World Tables (1995), The World Bank.

Data sources: OECD (1994), DSTI(STAN).

OECD (1994). DSTI(STAN/ANBERD).

OECD (1994). DSTI(STAN/BTD).

OECD (1994). DSTI(ISDB).

Table A1. Correlation Matrix

\section{Appendix}

\begin{tabular}{|c|c|c|c|c|c|c|c|}
\hline & MEU & MNEU & ITSP & GAP & RD & RDINT & MOECD \\
\hline MEU & 1.00 & & & & & & \\
\hline MNEU & 0.26 & 1.00 & & & & & \\
\hline ITSP & 0.16 & $\overline{0.11}$ & 1.00 & & & & \\
\hline GAP & -0.09 & -0.06 & -0.01 & 1.00 & & & \\
\hline RD & 0.25 & 0.14 & 0.80 & -0.04 & 1.00 & & \\
\hline RDINT & 0.085 & -0.03 & 0.64 & -0.06 & 0.58 & 1.00 & \\
\hline MOECD & 0.11 & 0.83 & 0.25 & -0.03 & 0.32 & 0.15 & 1.00 \\
\hline
\end{tabular}

